HOW

Volume 28, Number 3, pages 134 - 153

https://doi.org/10.19183/how.28.3.679

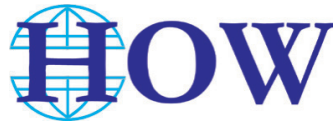

\title{
On the Professional Development of English Teachers in Colombia and the Historical Interplay with Language Education Policies
}

\author{
Sobre el Desarrollo Profesional de los Docentes de Inglés en \\ Colombia y la Relación Histórica con las Políticas Lingüísticas \\ Educativas
}

\section{Adriana González-Moncada ${ }^{1}$}

\begin{abstract}
The professional development of English teachers is a significant area in language teaching and learning, as well as in teacher education. On the one hand, at least in theory, professional development initiatives respond to the teachers' changing needs. On the other hand, it reflects the beliefs that different educational authorities and stakeholders have about English uses and education. In this self-study, I consider the professional development of English teachers in Colombia and its tight connection to the language education policies of the country. Following a chronological approach, I present the findings as landmarks that have contributed to my reflections and research around professional development and language education policies. Discussing the findings, I show how the discourses and decisions about teachers' continuing learning represent certain views of language, second language acquisition, English language teaching and learning, and teachers as professionals. This self-study addresses some of the concepts that illuminate the discourses that have shaped English teachers' professional development. Focusing primarily on the development of the National Program of Bilingualism, I underscore the power of these concepts over the major decisions made at the local and school levels. In the analysis of the past and present of teachers' professional development in Colombia, I conclude on the necessity
\end{abstract}

She holds a doctoral degree in Linguistics from the State University of New York at Stony Brook. She is a professor at the Universidad de Antioquia in the undergraduate and graduate foreign language teacher education programs. Her areas of academic work include teacher professional development, language policies, World Englishes, and ELF.

adriana.gonzalez1@udea.edu.co

ORCID ID: https://orcid.org/0000-0002-4522-0424

Received: July 19th, 2021. Accepted: July 26th, 2021.

This article is licensed under a Creative Commons Attribution-Non-Commercial-No-Derivatives 4.0 International License. License Deed can be consulted at https://creativecommons.org/licenses/by-nc-nd/4.0. 
of maintaining critical scholarly work to contribute to the construction of local knowledge for future reflection.

Keywords: colonialism, language education policies, National Program of Bilingualism, nativespeakerism, self-study, teachers' professional development

\section{Resumen}

El desarrollo profesional de los docentes de inglés es un área importante en la enseñanza y aprendizaje de la lengua, al igual que en la formación de docentes. De un lado, al menos en teoría, las iniciativas de desarrollo profesional responden a las necesidades cambiantes de los docentes. Del otro, reflejan las creencias que diferentes autoridades y actores educativos tienen sobre los usos del inglés y la educación en lenguas. En este autoestudio, trato la estrecha relación entre el desarrollo profesional de los docentes de inglés en Colombia y las políticas lingüísticas educativas del país. Siguiendo una perspectiva cronológica, presento los hallazgos como referentes que han contribuido a mis reflexiones e investigaciones sobre el desarrollo profesional y las políticas lingüísticas educativas. En la discusión de los hallazgos, demuestro cómo los discursos y las decisiones sobre el aprendizaje permanente de los profesores representan ciertas visiones de la lengua, de la adquisición de segundas lenguas, de la enseñanza del inglés y su aprendizaje, y de los docentes como profesionales. Este autoestudio trata algunas de las bases teóricas que inspiran los discursos que han definido el desarrollo profesional de los docentes de inglés. Enfocándome principalmente en el Programa Nacional de Bilingüismo, resalto el poder de dichos conceptos sobre las principales decisiones que se toman a nivel local y en las escuelas. En el análisis del pasado y del presente del desarrollo profesional de los docentes de inglés en Colombia, concluyo con la necesidad de mantener una academia crítica que contribuya a la creación de conocimiento local para futuras reflexiones.

Palabras clave: autoestudio, colonialismo, desarrollo profesional docente, hablante-nativismo, políticas lingüísticas educativas, Programa Nacional de Bilingüismo

\section{Introduction}

This article reports the findings of a personal history self-study (Samaras, 2002; Sampras et al., 2004) in which I analyze my academic journey in studying the needs, programs, and outcomes of the professional development (PD) of Colombian teachers of English in its connection to language education policies. Although some people may conceive them as separate areas, they do not work independently. Under the growing universal set of areas in Applied Linguistics, language learning and teaching, teachers' development, language policies, the study of contexts and discourses, Second Language Acquisition (SLA), among other fields, share their interest as a language-centered problem-solving enterprise (Grabe, 2010). The interconnection is more evident as teacher education and English language teaching (ELT) tend to focus more on learning than on methods (Kumaravadivelu, 2003), and SLA research underscores the role of contexts on individuals (for example, Firth \& Wagner, 2007; Ortega, 2009). To respond to the invitation from the journal HOW, I self-analyze my 
contributions to the field of English language teaching (ELT) in Colombia. The self-study uses a chronological analysis of my teaching and research career. I cover two decades of English teachers' PD and its connection to language education policies. For the readers of this article, I clarify that the references about language policies in the country come primarily after the launching of Bilingual Colombia in the 2000s.

The paper follows this structure: First, I refer to the concepts of teachers' PD and language education policies, the two broader areas in the study. Then, I describe the methodology that I used in the self-study. Later, I present the findings as landmarks in my own PD studying and researching the two topics. The discussion includes elaborations on other academic areas that have enriched my interest. I support the analysis through the connection to national and international references. To conclude, in the analysis of the past and present of teachers' PD in Colombia, I claim the need to maintain critical scholarship on language education policies. My aim is contributing to the construction of local knowledge for future reflections and action on English teachers' career learning. Regulations, discourses, and curricular decisions made by the governments have always affected English teachers' PD and will continue to do so.

\section{Conceptual Framework}

In this section, I develop the concepts of teachers' PD and language education policies as the primary concepts that frame this self-study. I situate the concepts in the framework of transformative pedagogy, as I believe that it leads to praxis. As Farren (2016) summarizes it, transformative pedagogy "has a moral as well as a social commitment to bringing about personal and social transformations by making connections between teaching and learning and living" (p. 192).

\section{Teachers' Professional Development}

As many authors say, defining teachers' PD is difficult, but all agree that it is continual and requires teachers' motivation and agency (Díaz-Maggioli, 2004). Díaz-Maggioli (2003) sustains that through PD "educators fine-tune their teaching to meet student needs" (p. 5).

136 It may include "a range of activities - formal (accredited) and informal (nonaccredited) which meet the thinking, feeling, acting, life, context and change purposes of teachers along their teaching careers" (Day \& Sachs, 2004, p. 12). Postholm (2012) adds that schools play a primary role in PD when teachers observe and reflect on their teaching through collaborative tasks with colleagues.

Understanding English teachers' PD includes considering how the professional and personal lives of teachers concur in their learning experiences in their in-service trajectories 
(Fessler \& Christensen, 1992). Teachers learn from personal and collective experiences in the classrooms and in society. Freeman (2006) summarizes a number of principles for teacher education and career-long learning: teachers have a learning process; teachers learn in and from situations of practice; teachers and students have different -but interrelated- experiences in classrooms; what teachers know and do influences -but does not cause- students to learn; and teacher training and development are vehicles for teacher learning.

Teachers' PD does not exist in a vacuum. Cochran-Smith (2006) contributes to expanding the notion of teachers' growth in the intricate connection between policy, politics, teacher education, and professional development. In the same vein, Sachs (2007) relates teachers' PD to policies and politics. About this connection, she states that,

Clearly, the continuing professional development of teachers is important to maintain and sustain a competent teaching profession. Moreover, at different times it serves different purposes and masters and hence is a political activity. The politics of curriculum content, pedagogy, and relationships within schools can all be sites of struggle, which should not be underestimated. (p. 18)

Sachs (2007) defines PD as a possibility for reimagining oneself and the profession through collective and autonomous inquiry that leads to transformation and change.

Teachers' PD as a space for new dimensions of the self takes distance from a deficit model. Wallace (2009) defines that perspective as an explanation of educational problems as the individual's responsibility. Usually, they are explained as lack of effort and commitment rather than as the result of the socio-economic conditions or the educational system, which affect the individual. In the deficit model, teachers have an enormous responsibility of educational problems. If learners have some poor academic performance, English teachers are to blame. Therefore, educational authorities see professional development programs (PDP) as the solution because they change the individual teachers' behavior or provide them with certain skills.

A primary consequence of analyzing PD from a deficit model is interpreting differences as a deficiency and denying the possibilities of diversity (Harry \& Klingner, 2007). This lens is particularly evident for the PDP that focus on imported approaches for the development of English teachers' language proficiency and teaching methodologies. This leads to the imposition of certain language varieties, forms, and uses and pre-conceived ELT packages (Kumaravadivelu, 2003). Below, I address specifically how the teachers' language proficiency and use of ELT methodologies have represented a major component of PD initiatives.

\section{Language Education and Language Education Policies}

Theories of language policies and language education policies have shaped ELT as they provide elements for the understanding of macro decisions that affect students, teachers, schools, and classrooms. Spolsky (2017) defines language policy as a field and as a "document 
produced in the course of language management" (p. 5). It encompasses three interrelated components: One, practices, or community language behaviors; two, beliefs and ideologies, meaning desirable language behavior; and three, management, that is how stakeholders influence language practices and beliefs in a community. Shohamy (2006) sees language policies as imposed mechanism that shapes the uses of languages in communities. She defines language education policies as "the mechanism used to create de facto language practices in educational institutions" (p. 76). Johnson (2013) adds another aspect changing the concept to educational language policy. He underscores the dynamicity and multilayered condition of language policies in schools and outside schools "that impact language use in classrooms and schools" (p. 54). Analysis of language policies and language education policies associate English to imperialism (Phillipson, 1992) and colonialism (Pennycook, 1998). I refer below to the National Program of Bilingualism (NPB) as a language education policy that has imposed certain practices in schools, in teacher education, and in teachers' professional development.

\section{Methodology}

In the analysis of my academic interest in English teachers' PD and language education policies, I drew on historical self-study as the methodology. As Samaras (2002) and Samaras et al. (2004) state, self-studies help us understand and renew our identity, and support our interpretation of the reality. Dinkleman (2003) underscores the power of self-studies in promoting reflection that leads to reflective teaching. Samaras et al. (2004) find historical self-studies beneficial because it allows educators "to reconstruct significant life events to inform them of their professional identity formation and to help them make meaning of their pedagogy and the connections of their practice to theory" (p. 906). In a local study, Clavijo and Ramírez (2018) recommend self-studies as a way to transform English teachers' professional identities and trajectories.

Data collection included as primary sources a timeline of my professional career, retrospective notes about my work as a researcher and professor, and a meta-analysis of my publications. I complemented the analysis discussing them in relation to the work of other local scholars, and through documentary analysis of some official communications and publications about these two areas. I focused on official documents produced after the launching of the NPB in the early 2000s. Data analysis followed a grounded theory approach as I coded the data though constant analysis to construct the categories (Glasser 1998; Saldaña, 2016).

\section{Findings and Discussion}

The historical self-study analysis of my work on English teachers' PD and language education policies allowed me to identify five landmarks in my career as a teacher educator 
and researcher. Each landmark favored my understanding of the two topics in my scholarly work. Around each landmark, I elaborate on the relationship of the macro discourses about teachers' PD and language education policies in their connection to theoretical approaches to language, second language acquisition, English language teaching and learning, and teachers as professionals.

\section{The Evolution of PD in my Professional Career}

Although my pre-service education at Universidad de Antioquia did not include research as a major component (Zambrano Leal, 2012), I was aware of the need to grow professionally after graduation. I was a student-teacher who worked at a school in the mornings and took classes at the university in the afternoons and evenings. The basic instruction on how to conduct classroom research motivated me to put into practice what I learned as if I had a long practicum training that lasted various years. An important piece of knowledge I received through the example of some professors came under the necessity of being a committed professional, a reflective practitioner and an agent of change (Schön, 1986). I also realized that I needed to improve my English language proficiency and keep updated in the use of English language teaching (ELT) methodologies. A primary question was how I could keep learning in my ELT career.

\section{The First Landmark: My Doctoral Research}

My interest in exploring why some English teachers seemed to lose their language skills while others maintained them or improved them in their professional career became more evident in my doctoral training. I proposed the first study in TESOL that involved the language attrition of non-native English-speaking teachers (NNEST). I collected the data in Colombia and compared the linguistic trajectories of a group of teachers from public and private schools in their proficiency and use of English inside and outside the classrooms (González, 1995). Colombian pre-service students served as the comparison group to determine language attrition or retention of English teachers in both settings (Weltens \& Cohen, 1989).

I demonstrated that English teachers in public schools experienced language attrition, while private school teachers maintained their language proficiency after graduating from the teacher education program. Public school teachers experienced conditions that were unsupportive of their English language practice, had limited access to teaching materials, and did not have access to other speakers. On the contrary, teachers in private schools and language centers reported increasing, or at least maintained their language skills after university graduation.

At the time, mainstream SLA research, and consequently, language proficiency, focused mainly on the individual differences in language learning and the dichotomy native-nonnative 
speakers (Ortega, 2009). The ideal native speaker was the model to imitate in English language learning and teaching in cognitive approaches in SLA (for example, O'Malley \& Uhl Chamot, 1990 , among others). The individual characteristics that favored or hindered the acquisition of a second language were a primary component of teacher education and professional development (for example, Oxford, 1990; Ellis, 1994, among many).

Nonnative speakers were considered from a deficiency and incomplete stand, defined in comparison to the native speaker. Teachers had the challenge to compensate for that lack of knowledge through remedial linguistic or methodological training, as various authors demonstrate it in Blyth (2003). This was more evident for the oral production of English language learners (Flege \& Fletcher, 1992; Flege \& Eefting, 1988).

Although my study was eminently linguistic and quantitative, I found evidence of how school and social contexts played a role in the attrition or retention of English among local teachers (Gardner et al., 1985, 1987). The findings were in alignment with studies that highlighted the role of social contexts (De Bot \& Weltens, 1995; Gardner et al., 1985, 1987; Weltens \& Grendel, 1993).

The literature on the types of PDP available to Colombian teachers before the NPB is scarce. Ramos Acosta (2019) states that in the 1980s English teachers relied on "short courses or workshops taught by experts that selected some content to transmit it as the only formula for the successful teaching of the language" (p. 64). Later, the 1994 General Law of Education defined the route for teacher education by introducing two significant articles "the acquisition of conversation and reading elements in at least a foreign language" for elementary education, and for high school, "comprehension and the capacity to communicate in a foreign language" (Ministerio de Educación Nacional, 1996, p. 8). Zambrano (2012) states that, after the promulgation of that law, the terms "capacitación" and "formación" became evident in the field.

After the General Law of Education, the PDP available stressed the use of updated methodologies and the teachers' language skills in English, responding to the principles of "teacher training" (Freeman, 1989; James, 2001). The PDP responded to what Ur (1997) shows: imposed agendas, externally determined and assessed, designed by experts, isolated, and focused on the mastery of professional skills. One example of this view is Restrepo 140 (1995). For Antioquia, the PPD stressed the importance of providing teachers with teaching methodologies, creating a space for language practice, and training them on cultural aspects of the countries where the foreign languages came from. In Neiva, Vanegas Rubio and Zambrano Castillo (1996) proposed a training program for elementary school teachers based

Some possible translations into English are "training or qualification". Although the term is controversial, it is still in use. 
on the acquisition of basic English communication skills, ELT methodologies and assessment for elementary education, and children's socio-affective-linguistic development. The authors reported that "the majority of elementary teachers ... only have their high school English instruction, which they assess as not very good" (p. 40). Quintero and Guerrero (2013) provide a current analysis of English teachers in elementary education in the country.

A significant contribution to the PD of teachers was the Colombian Framework for English, known as the COFE project. Developed in collaboration with Thames Valley University, the project began in 1991 and lasted until 1997. It influenced a generation of teacher educators and English teachers with an academic and critical stand on the profession. Rubiano et al. (2000) reported as the major achievements the improvement of the language component in pre-service programs, new approaches to the teaching practicum, the development of research in the field, and the acquisition of teaching resources and specialized professional literature.

\section{The Second Landmark: Studying the Professional Needs of English Teachers}

In the early 2000s, I led a study that explored the topics and strategies that English teachers in Medellín identified as key components of their PD (González et al., 2001, 2002). Findings showed how English teachers sought to maintaining their language proficiency as a major motivation to participate in PDP. Then, they also looked for the expansion and update of their teaching methodologies in response to the changes in their students' needs. English teachers also expressed their desire to be acquainted with educational theories beyond pedagogy and linguistics to face their daily challenges in complex social contexts. Finally, they were eager to have spaces to share what they learned with their peers, and if possible, to receive monetary compensation or recognition for their work in the PDP.

The study confirmed how limited the opportunities for PD were at the time. The primary source of in-service teachers' learning was the local ELT conference, and the sporadic publishing companies' teacher training sessions. The participants identified pursuing graduate studies as a powerful way to grow professionally; yet, programs were scarce, expensive, and theoretically or research oriented. Finally, English teachers claimed the urgency to propose PDP that responded to the particularities of their settings and included their voices in the design (González, 2003).

These findings also showed that PDP available at the time reproduced the deficit model in education (Wallace, 2009) in which teachers required intervention to "fix" their limitations, mainly in English proficiency and ELT methodologies. In an analysis of PD in Colombia, Buendía and Macías (2019) point out that teachers' claims of many years ago still seem to 
be unresolved. The authors emphasize the absence of a critical approach to teachers' PD in the country.

\section{The Evolution of Language Education Policies in my Professional Career}

\section{The Third Landmark: The Launching and Development of the NPB}

This was the first connection that I made between PD and language policies. Taking part in the preliminary stages of the formulation of the national English standards (Ministerio de Educación Nacional, 2006b) allowed me to develop a critical view of the process. At the time, I became a member of the board of directors of the Colombian Association of Teachers of English (ASOCOPI, in Spanish). Thanks to the collective reflection in a national study on the university-based PD opportunities for English teachers, the research team gained more awareness of the connection between the policy discourses and the views of teachers' education and professional growth. We demonstrated how most PDP in the country responded more to interests of coverage over continuity and quality (Álvarez et al., 2011). Additionally, the study revealed the open view of teachers' PD from a deficit perspective, as clearly stated in Cely (2007) and Hernández (2007). To contend the topdown approaches to professional development, the research group insisted on the need of a bottom-up, democratic, and reflective framework that could support the creation of local knowledge (Cárdenas et al., 2010).

Various local and national events became spaces for interesting discussions and reflections. The 2005-2010 quinquennium was of particular importance in my understanding and analysis of the PD of Colombian English teachers. The work of colleagues from various universities represented an opportunity for consolidating and making internationally visible local knowledge around language policies and PD (Agray Vargas, 2008; Ayala \& Álvarez, 2005; Cárdenas, 2006; Kostina \& Hernández, 2007; Hernández \& Faustino, 2006; Guerrero, 2008, 2010; Sánchez \& Obando, 2008; Usma, 2009; among others). Although critical voices seemed to be predominant in the academic literature on the NPB, especially that coming

142 from public universities, others openly advocated for the way the NPB was designed and implemented (Angarita Trujillo \& Arias Castilla, 2010; Cely, 2007; Hernández, 2007). Other scholars proposed intermediate analysis of the policy (de Mejía, 2004, 2007; Herazo et al., 2012, for example).

In González (2007, 2009a, 2009b), I analyzed critically the NPB's views of English teachers' PD and teacher education. Generalizing a view of teachers, and revealing a deficit approach (Wallace, 2009) from decision makers, Colombian English teachers appeared as 
incompetent professionals with limited language proficiency and inadequate methodologies (Guerrero, 2010). The Ministry of Education (MoE) announced as a primary solution the adoption of international certifications such as the In-service Certificate in English Language Teaching (ICELT) and the Teaching Knowledge Test (TKT) (González, 2009b). The TKT was mentioned as the best alternative to measure the teachers' use of ELT methodologies (Ministerio de Educación Nacional, 2006b). It was also recommended as a primary axis in the curriculum in English teachers' pre-service education. The ICELT became the holy grail of PDP for in-service English teachers. The British Council selected a group of teacher educators that, using a cascade model, committed to replicate it creating various cohorts of trainees (Angarita Trujillo \& Arias Castilla, 2010). Granados (2015), Gómez Sará (2017), Le Gal (2018), and Valencia (2013) agree with the analysis in González (2009a). It is undeniable that the PD of English teachers and teacher education became a profitable business that has benefited foreign agencies, publishing, and testing companies since the beginning of the NPB (González, 2007; Usma, 2009; Valencia, 2013).

\section{The Fourth Landmark: My Participation in the Creation of the Master's Program in Foreign Language Teaching and Learning at Universidad de Antioquia}

Working with colleagues that pursued their doctoral degrees in the United States in institutions that had a critical perspective in Applied Linguistics and Education provided me with new insights on the connection of teachers' work and language policies (Shohamy, 2009). Through a study on the implementation of the NPB in the State of Antioquia, the research team gained a deep understanding of the English teachers' needs and how different stakeholders understood professional development. The different voices allowed us to comprehend the gap between the policy intentions and the real implementation of the NPB (Correa \& González, 2016; Correa \& Usma, 2013; Correa, Usma, \& Montoya, 2014).

As part of the research line in PD to which I affiliated in the mater's program, I led a study on how English teachers understood and appropriated the NPB in urban schools in five municipalities of the Metropolitan Area of Medellín. Through the voices of the teachers, I identified the complexity of the discourses of the policy at the macro, meso, and micro level because they shaped ELT and learning (The Douglas Fir Group, 2016), teacher education and teachers' professional development (Ministerio de Educación Nacional, 2013). I found more elements of the imposition of the agendas (González, 2015) and traces of native-speakerism (Holliday, 2006, Llurda, 2005) in a number of the PDP. I refer to this issue below.

Findings of the study reflect Day's (2005) appraisal about teachers' motivation and commitment as key components in professional growth. However, for teachers "both their working contexts and their personal values and circumstances" (p. 111) shape them. Data 
showed that although individual agency is determinant, it is not enough. The influence of the working conditions and circumstances limit the teachers' room for action and reaction. Those challenges have not received enough consideration in many PDP proposals in Colombia (Alvarez et al., 2011; Chaves \& Guapacha, 2016). As Agray Vargas (2008) stated it, there is an open contradiction in the language education policies. On the one hand, policies stress the necessity of having reflective, critical, and committed teachers; but on the other hand, "the actions promoted to qualify the foreign language teacher head to following unique teaching, learning, assessment, and teacher education models designed, piloted, and implemented without considering the socio-economic, political, and cultural context" (Agray Vargas, 2008, p. 355).

\section{The Fifth Landmark: Working with International Colleagues}

Research conducted at Universidad de Antioquia and in Colombia on the topic of language policies and teachers' PD from a critical stand allowed me to connect it to wider perspectives on the uses of English. This learning facilitated the exploration of World Englishes (WE) as a pluralistic approach (Kachru, 1992; Kirkpatrick, 2007). WE stress the value of plurilingual and pluricultural contexts in the definition of English, its uses, its teaching, and learning. One of the primary contributions of WE is the tenet on the value of nonnative speakers of English. The contributions of WE motivated my interest in exploring national sociolinguistic discourses about English (Schneider, 2018). Focusing my research on the Colombian context, I contributed with an update of the seminal work of Vélez-Rendón (2003). González (2020) analyzed the 2010-2020 decade relating the status of English, ELT, and language policies in the Expanding Circle. Teachers' PD and teacher education are part of the review.

Although part of the initial critical issues of the NPB lost the attention of a number of scholars, I maintained my critical view because the different names of the policy maintained a pervasive colonial approach (Pennycook, 1998) through the magnification of the work of foreign agencies and foreign teachers to guarantee the NPB success (for example, Ministerio de Educación Nacional, 2016). A clear expression of the continuity of the NPB colonial practices in professional development, which I described in González (2007), were evident in the formulation of the Formadores Nativos Extranjeros ${ }^{3}$ (Foreign native [speaker] instructors) strategy. In González and Llurda (2016), we questioned the extension of the concept of NEST to a foreign instructor who had a C1 level of proficiency in the CEFR. That strategy discriminated Colombian teachers who had the demanded profile demanded just because they were not foreigners.

The title is ambiguous in Spanish. To make a grammatical phrase in English, I added the noun "speaker". According to the MoE, hiring native speakers of English was one of the assets of the strategy. 
By connecting language policies and WE, I expanded the notion of native-speakerism (Holliday, 2006; Llurda, 2005). Through our participation in a study of the discourses of the Latin American press on NNESTs, we found unfortunate practices that reinforced the NESTs as the ideal support for the English policy success. Through the open endorsement of the government, various countries of Latin America used native-speakerism as an academic action (González \& Llurda, 2016). The frequent use of foreign scholars, teachers, teacher-training models, and the emphasis on immersion programs abroad perpetuated the superiority of foreign ideas over local approaches (Cronquist \& Fiszbein, 2017; González, 2020). In the same line, MacKenzie (2020) concluded that native-speakerism is present in the ELT job market in the country. Viáfara (2016) concluded the same in his analysis of preservice teachers, showing the influence of native-speakerism ideologies in teacher education.

Studying native-speakerism allowed me to explore the field of English as a Lingua Franca (ELF). Multilingual speakers who do not have it as a common language but use it as a medium of communication (Seidlhofer, 2006, 2011) define ELF as the use of English. My understanding of ELF gained a different dimension under the influence of some Brazilian scholars. From their ELF perspective, a critical decolonial framework for ELT is an evident contribution as it underscores the ecological perspectives, promotes diverse uses of English, and challenges the power granted to native speakers and centralized theories. They have shown ELF's connection to teacher education and professional development (Duboc, 2018; Duboc \& Siqueira, 2020; Gimenez et al., 2018; Siqueira, 2015).

Another important concept from Brazilian scholarship is the open questioning of the preconceived idea of language heterogeneity (Pessoa de Farias, 2015). The author demonstrates how speakers of any language tend to resist language diversity and express preconceived ideas "maintaining discourses that reject the existence of language verities" ( $p$. 463). This position is reinforced in language education policies that stress the value of certain English varieties over others. Pessoa Farias (2015) insists on "the relevance of analyzing, discussing, and questioning the relationships between the practices and representations about a given language community. Based on them, it is possible to unveil the hidden agendas of the language policy" (p. 481).

Despite growing voices on critical perspectives in professional development, the power of the deficit approach is very strong (Harry \& Klingner, 2007). Under varied fixed discourses, decolonial concepts such as WE or ELF will take a long time to be part of the PDP that teachers have access to in our country. Studies in the English periphery, such as those by Sikafis $(2009,2014)$ in Greece, Bayyurt and Sifakis (2015) as well as Sifakis and Bayyurt (2017) in Turkey and Greece, or Gimenez et al. (2018), could enlighten our proposals to professional development. They hold an asset-based approach that considers teachers as competent multilinguals that possess valuable teaching experience and significant knowledge of their contexts. 


\section{Conclusions and Limitations}

My current understanding of PD and language education policies is the result of the five landmarks I described above. My understandings of PD, and later, of language education policies, responded initially to the theories that dominated the field. Later, through collaborative work with national and international colleagues, I developed the critical stand I currently hold. I have demonstrated through my historical self-study that English teachers' PD should respond to teachers' needs and wider connections to the real uses of the language at the social level. PDP should transcend the deficit model reflected in the national government and societal discourses. They stress individual teachers' responsibility on language learning and teaching, and therefore, on the language policy success.

Language education policies, despite the possible room for agency in their appropriation (Hornberger \& Johnson, 2007; Menken \& García, 2010), tend to perpetuate the power of certain English varieties, and therefore, favor tendencies such as native-speakerism. That power is very strong and allows limited space for teachers' action. The last quinquennium 2015-2020 shows the same power of the external policy actors because they have the governments' endorsement, and therefore, inspire credibility on many stakeholders (González \& Llurda, 2016; González, 2020).

After this chronology of my work on the PD of English teachers and language education policies, I can state that my primary contribution to the field has been showing how issues of power at the macro and meso levels of the language education policy keep affecting English teachers' work in the country. This has happened mainly in public education where contexts are diverse, and inequity is evident. I have also sustained the need to challenge the colonial perspectives in ELT and PD keeping a critical stand and opening the horizons to conceptual frameworks such as WE and ELF.

As this paper reports a self-study, I am aware of the bias I may have. Some colleagues may not share my academic position as they associate it with a historical-structural approach to language education policies (Tollefson, 2002). Some may claim that I seem to deny the power of agency of policy actors in the policy appropriation process. They may say that my arguments tend to be quite deterministic of the effects of the power issues that I have

146 underscored. Although I believe that teachers and students have the power of innovation, resistance, and contestation, I find it very limited in reality. I usually remember Sherlock Holmes idea that "there is nothing more deceptive than an obvious fact".

Responding to HOW journal's question about the impact of my work, I need to be cautious. I cannot deny that holding a tenured position in a public university, acquainted with critical opinions and political debates, works in my favor. At the initial stage of the $\mathrm{NPB}$, I was probably one of the first critical voices of the policy. I dared to say publicly 
in different academic spaces what I found questionable, mainly in the role of the British Council. According to Íkala journal metrics, González (2007) has more than 300 national and international citations. González (2009b) and (2015) also have numerous citations on Research Gate and Academia. Maintaining that critical voice has probably made my work visible and subject to criticisms. In González (2020), and some forthcoming papers, I extend the critical lens to the educational language policy because I have seen very little change in the official discourses and the decisions made at national and local levels about ELT and teachers' professional development. However, I keep my spirits high about the future. One day, we will have new directions in the language education policies; therefore, there will be changes in the PD of English teachers.

\section{References}

Agray Vargas, N. (2008). ¿Qué le pide hoy la sociedad colombiana a un profesor de lenguas extranjeras? [What does the Colombian society demand from a foreign language teacher?] Signo $y$ Pensamiento, 27(53), 352-357. https://www.redalyc.org/pdf/860/86011529023.pdf

Álvarez, J. A., Cárdenas, M. L., \& González, A. (2011). Cobertura vs continuidad: dos retos para el desarrollo profesional para los docentes de inglés en el marco de Colombia Bilingüe. In J. A. Bastidas, \& G. Muñoz, Fundamentos para el desarrollo profesional de los profesores de inglés (pp. 119-154). Universidad de Nariño.

Angarita Trujillo, A. E., \& Arias Castilla, A. (2010). Aproximación a los antecedentes del bilingüismo en Colombia y la formación de educadores bilingües. Horizontes Pedagógicos, 12(1).

Ayala, J., \& Álvarez, J. A. (2005). A perspective of the implications of the Common European Framework implementation in the Colombian socio-cultural context. Colombian Applied Linguistics Journal, 7, 7-26. https://doi.org/10.14483/22487085.162

Bayyurt, Y., \& Sifakis, N. C. (2015). ELF-aware in-service teacher education: a transformative perspective. In H. Bowles \& A. Cogo (Eds.), International perspectives on English as a lingua franca: Pedagogical insights (pp. 117-136). Palgrave Macmillan.

Blyth, C. (Ed.) (2003). The sociolinguistics of foreign-language classrooms: Contributions of the native, the near-native, and the nonnative speaker. Issues in Language Program Direction. Heinle.

Buendía, X., \& Macías, D. F. (2019). The professional development of English language teachers in Colombia: A review of the literature. Colombian Applied Linguistics Journal, 21(1), 80-102. https://doi.org/10.14483/22487085.12966

Cárdenas, M. L. (2006). Bilingual Colombia: Are we ready for it? What is needed? Proceedings of the 19th Annual English Australia Education Conference. Online. http://www.englishaustralia.com.au/ea_conference2006/proceedings/.

Cárdenas M. L., González A., \& Álvarez J. (2010). In-service English teachers’ professional development: Some conceptual considerations for Colombia. Revista Folios, 31(1), 49-68. https:// doi.org/10.17227/01234870.31 folios49.67 
Cely, R. M. (2007). Programa Nacional de Bilingüismo: En búsqueda de la calidad en educación. Revista Internacional Magisterio, 25, 20-23.

Chaves, O., \& Guapacha, M. E. (2016). An eclectic professional development proposal for English language teachers. Profile: Issues in Teachers' Professional Development, 18(1), 71-96. https://doi. org/10.15446/profile.v18n1.49946

Clavijo, A., \& Ramírez, M. (2018). Using self-study to examine our research and teaching practices as EFL teacher educators in Colombia. In J. Sharkey \& M. Peercy (Eds), Self-study of language and literacy teacher education practices (pp. 37-53). Emerald Publishing Limited. https:/ / doi.org/10.1108/S1479-368720180000030003

Cochran-Smith, M. (2006). Policy, practice, and politics in teacher education. Sage Publications.

Correa, D., \& González, A. (2016). English in public primary schools in Colombia: Achievements and challenges brought about by national language education policies. Education Policy Analysis Archives, 24(83). https://doi.org/10.14507/epaa.24.2459

Correa, D., \& Usma, J. (2013). From a bureaucratic to a critical-sociocultural model of policymaking in Colombia. HOW, 20, 226-24.

Correa D., Usma J., \& Montoya J. C. (2014). National Bilingual Program: An exploratory study in the department of Antioquia, Colombia. Íkala, 19(1), 101-116.

Cronquist, K., \& Fiszbein, A. (2017) English language learning in Latin America. The Dialogue.

Day, C. (2005). Stories of change and professional development. The costs of Commitment. In C. Day, A. Fernández, T. Hauge, \& J. Møller (Eds). The Life and work of teachers. Routledge Falmer.

Day, C., \& Sachs, J. (2004). Professionalism, performativity and empowerment: Discourses in the politics, policies and purposes of continuing professional development. In C. Day \& J. Sachs (Eds.), International Handbook on the Continuing Professional Development of Teachers (pp. 3-32). Open University Press.

De Bot, K., \& Weltens, B. (1995). Foreign language attrition. Annual Review of Applied Linguistics, 15, 151-164.

Díaz-Maggioli, G. (2003). Professional development for language teachers. Eric Digest EDO-FL, 03-03.

Diaz-Maggioli, G. (2004). Teacher-centered professional development. ASCD.

de Mejía, A. M. (2004). Bilingual education in Colombia: Towards an integrated perspective. Bilingual Education and Bilingualism, 7(4), 381-97.

de Mejía, A. M. (2007). Visiones del bilingüismo y de la educación bilingüe en Colombia. Revista Internacional Magisterio, 25, 36-39.

Dinkleman, T. (2003). Self-study in teacher education: A means and ends tool for promoting reflective teaching. Journal of TeacherEducation, 54(1), 6-18. https://doi.org/10.1177/0022487102238654

Duboc, A. P. (2018). The ELF teacher education: Contributions from postmodern perspectives. In T. Gimenez, M. El Kadri, \& L. Calvo (Eds.), English as a lingua franca in teacher education: A Brazilian perspective (pp. 159-188). De Gruyter Mouton. 
Duboc, A. P., \& Siqueira, S. (2020). ELF feito no Brasil: Expanding theoretical notions, reframing educational policies [English made in Brazil]. Status Quaestionis, 2(19), 231-258. https://doi. org/10.13133/2239-1983/17135

Ellis, R. (1994). The study of second language acquisition. Oxford University Press.

Farren, P. (2016). Transformative pedagogy in the context of language teaching: Being and becoming. World Journal on Educational Technology: Current Issues, 8(3), 190-204.

Fessler, R., \& Christensen, J. (1992). The teacher career cycle. Allyn and Bacon.

Firth, A., \& Wagner, J. (2007). Second/Foreign language learning as a social accomplishment: Elaborations on a reconceptualized SLA. The Modern Language Journal, 91(s1), 800-819. https://doi.org/10.1111/j.1540-4781.2007.00670.x

Flege, J., \& Eefting, W. (1988). Imitation of a VOT continuum by native speakers of English and Spanish: Evidence for phonetic category formation. Journal of the Acoustic Society of America, 83(2), 729-740.

Flege, J., \& Fletcher, K. (1992). Talker and listener effects on degree of perceived foreign accent. Journal of the Acoustic Society of America, 91(1) 370- 389.

Freeman, D. (1989). Teacher training, development and decision making: A model of teaching and related strategies for language teacher education. TESOL Quarterly, 23(1), 28-46.

Freeman, D. (2006). A Framework for teacher learning and development. Paper presented at the TESOL Symposium on English Teacher Development in EFL Contexts. Shantou University, China. (November 10). https://www.tesol.org/docs/default-source/new-resource-library/ symposium-on-english-teacher-development-in-efl-5.pdf?sfvrsn $=0 \& s f v r s n=0$

Gardner, R., Lalonde, R. N., \& MacPherson, J. (1985). Social factors in second language attrition. Language Learning, 35(4), 519-540. https://doi.org/10.1111/j.1467-1770.1985.tb00359.x

Gardner, R., Lalonde, R. N., Moorcroft, R., \& Evers, F. T. (1987). Second language attrition: The role of motivation and use. Journal of Language and Social Psychology, 6, 29-47. https://doi. org/10.1177/0261927X8700600102

Gimenez, T., El Kadri, \& Calvo, L. (Eds.) (2018). English as a lingua franca in teacher education: A Brazilian perspective. De Gruyter Mouton.

Glaser, B. G. (1998). Doing grounded theory: Issues and discussions. Sociology Press.

Gómez Sará, M. M. (2017). Review and analysis of the Colombian foreign language bilingualism policies and plans. HOW, 24(1), 139-156. https://doi.org/10.19183/how.24.1.343

González, A. (1995). Language attrition and retention among nonnative speakers of English [Doctoral dissertation]. State University of New York at Stony Brook.

González, A. (2003). Who is educating EFL teachers? A Qualitative Study of In-service in Colombia. Íkala, 8(14), 153-172.

González, A. (2007). Professional development of EFL teachers in Colombia: Between colonial and local practices. Íkala, 12(1), 309-332. 
González, A. (2009a). Reflexiones sobre el bilingüismo en Colombia [Reflections on bilingualism in Colombia]. Revista El Educador, 2(7), 24-30.

González, A. (2009b). On alternative and additional certifications in English language teaching: The case of Colombian EFL teachers' professional development. Íkala, Revista de Lenguaje y Cultura, 14(22), 183-209.

González, A. (2015). ¿Nos han desplazado? ¿O hemos claudicado? El debilitado papel crítico de universidades públicas y los formadores de docentes en la implementación de la política educativa lingüística del inglés en Colombia. In K.A. Da Silva, M. Mastrella-de-Andrade, \& C. A. Pereira Filho (Eds.), A formação de professores de línguas: políticas, projetos e parcerias (pp. 3355). Pontes Editores.

González, A. (2020). English and English teaching in Colombia: Tensions and Possibilities in the Expanding Circle. In A. Kirkpatrick (Ed.), The Routledge handbook of World Englishes (2 ${ }^{\text {nd }}$ ed.) (pp. 371- 385). Routledge.

González, A., \& Llurda, E. (2016). Bilingualism and globalization in Latin America: Fertile ground for nativespeakerism. In F. Copland, S. Mann, \& S. Garton (Eds.), LETs and NESTs: Voices, views and vignettes (pp. 90-109). British Council.

González, A.; Montoya, C.; Claudia; \& Sierra, N. (2001). EFL Teachers look at themselves: could they grow together? HOW, special number 9, 27-33.

González, A., Montoya, C., \& Sierra, N. (2002). What do EFL teachers seek in professional development programs? Voices from teachers. Íkala, 7(13), 29-50.

Grabe, W. (2010). Applied Linguistics: A twenty-first-century discipline. In R. B. Kaplan (Ed.), The Oxford handbook of applied linguistics (2nd ed.) (pp. 34-44). Oxford University Press.

Granados, C. (2015). Formación inicial de docentes de lenguas extranjeras. Nodos y Nudos, 4(39), 59-69. https://doi.org/10.17227/01224328.4356

Guerrero, C. H. (2008). Bilingual Colombia: What does it mean to be bilingual within the framework of the National Plan of Bilingualism? Profile: Issues in Professional Development, 10, 27-45.

Guerrero, C. H. (2010). The portrayal of EFL teachers in official discourse: The perpetuation of disdain. Profile: Issues in Teachers' Professional Development, 12(2), 34-49.

Harry, B., \& Klingner, J. (2007). Discarding the deficit model. Educational Leadership, 64(5), 16-21.

Herazo, J. D., Jerez, S., \& Lorduy, D. (2012). Opportunity and incentive for becoming bilingual in Colombia: Implications for Programa Nacional de Bilingüismo. Íkala, 17(2), 199-213.

Hernández, F., \& Faustino, C. (2006). Un estudio sobre la enseñanza de lenguas extranjeras en colegios públicos de la ciudad de Cali. Lenguaje, 34, 217-250.

Hernández, L. J. (2007). Pertinencia de un modelo de metodología del inglés certificado internacionalmente. Revista Internacional Magisterio, 25, 32-35.

Holliday, A. (2006). Native-speakerism. ELT Journal, 60(4), 385-387. https://doi.org/10.1093/ elt/ccl030 
Hornberger, N. H., \& Johnson, D. C. (2007). Slicing the onion ethnographically: Layers and spaces in multilingual language education policy and practice. TESOL Quarterly, 41(3), 509-532.

James, P. (2001). Teachers in action: Tasks for in-service language teacher education and development. Cambridge University Press.

Johnson, D. C. (2013). Language policy. Palgrave Macmillan.

Kachru, B. (1992). The other tongue: English across cultures. University of Illinois Press.

Kirkpatrick, A. (2007). World Englishes: Implications for international communication and English language teaching. Cambridge University Press.

Kostina, I., \& Hernández, F. (2007). Competencia profesional del docente de lenguas extranjeras. In A. Aragón, I. Kostina, M. Pérez, \& G. Rincón (Eds.) (2007). Perspectivas sobre la enseñanza de la lengua materna, las lenguas y la literatura (pp. 81-99). Facultad de Educación de la Pontificia Universidad Javeriana.

Kumaravadivelu, B. (2003). Beyond methods: Macrostrategies for language teaching. Yale University Press.

Le Gal, D. (2018). Enseñanza del inglés en Colombia: Un necesario cambio de paradigma. Matices en Lenguas Extranjeras, 12.

Llurda, E. (2005). Looking at the perceptions, challenges, and contributions ... Or on the importance of being a non-native teacher. In E. Llurda (Ed.) Non-native language teachers: Perceptions, challenges and contributions to the profession (pp. 1-9). Springer.

MacKenzie, L. (2020). Discriminatory job advertisements for English language teachers in Colombia: An analysis of recruitment biases. TESOL Journal, e535. https://doi.org/10.1002/ tesj. 535

Menken, K., \& García, O. (Eds.). (2010). Negotiating language policies in schools: Educators as policymakers. Routledge.

Ministerio de Educación Nacional. (1996). Lineamientos curriculares en idiomas extranjeros. http://www.mineducacion.gov.co/1759/articles-339975_recurso_7.pdf

Ministerio de Educación Nacional. (2006a). Bases para una nación bilingüe y competitiva. Al Tablero, 37. https://www.mineducacion.gov.co/1621/article-97498.html

Ministerio de Educación Nacional. (2006b). Estándares básicos de competencias en lenguas extranjeras: inglés. Formar en lenguas extranjeras: jel reto! Lo que necesitamos saber y saber hacer. Series Guías No 22. MEN.

Ministerio de Educación Nacional (2013). Sistema colombiano de formación de educadores y lineamientos de politica. https://www.mineducacion.gov.co/1759/articles-345485_anexo1.pdf)

Ministerio de Educación Nacional, (2016). Modelo para la implementación de un programa de formadores nativos extranjeros. http://aprende.colombiaaprende.edu.co/sites/default/files/naspublic/ colombiabilingue $/ 2 \% 20$ Modelo $\% 20 \mathrm{de} \% 20$ implementaci $\%$ C3 $\%$ B3n $\% 20-\% 20$ Resumen $\% 20$ en $\% 20$ espa $\%$ C3\%B1ol.pdf

O’Malley, J. M., \& Uhl Chamot, A. (1990). Learning strategies in second language acquisition. Cambridge University Press. 
Ortega, L. (2009). Understanding second language acquisition. Hodder Arnold.

Oxford, R. (1990). Language learning strategies. What every teacher should know. Heinle \& Heinle.

Pennycook, A. (1998). English and the discourses of colonialism. Routledge.

Pessoa de Farias, L. F. (2015). Homogeneidade e intolerancia na linguagem [Homogeneity and intolerance in the language]. In S. C. Tavares de Souza \& M. P. Roca (Eds.), Politicas linguísticas declaradas, praticadas e percebidas (pp. 463-496). Editora da Universidade Federal da Paraíba, Brazil.

Phillipson, R. (1992). Linguistic Imperialism. Oxford University Press.

Postholm, M. B. (2012). Teachers' professional development: a theoretical review, Educational Research, 54(4), 405-429. https://doi.org/10.1080/00131881.2012.734725

Quintero, A., \& Guerrero, C. H. (2013). Of being and not being: Colombian public elementary school teachers' oscillating identities. HOW, 20, 156-177.

Ramos Acosta, L. (2019). Reflexiones sobre la formación de docentes de lengua extranjera en Colombia. Revista Boletín Redipe, 8(7), 61-72. https://doi.org/10.36260/rbr.v8i7.777

Restrepo, M. C. (1995). Programa de formación y perfeccionamiento pedagógico, lingüistico y cultural en lenguas extranjeras [Unpublished manuscript]. Secretaría de Educación y Cultura de Antioquia. Dirección de Currículo. División de Educación Formal. Medellín.

Rubiano C., Frodden C., \& Cardona G. (2000). The impact of the Colombian Framework for English (COFE) project: An insider's perspective. Íkala, Revista de Lenguaje y Cultura, 5, 38-54.

Sachs, J. (2007). Learning to improve or improving learning: the dilemma of teacher continuing professional development. $20^{\text {th }}$ Annual World International Congress for Effectiveness and Improvement. https://www.fm-kp.si/zalozba/ISBN/978-961-6573-65-8/009-020.pdf

Saldaña, J. (2013). The coding manual for qualitative researchers (2nd ed.). SAGE.

Samaras, A. P. (2002). Self-study for teacher educators: Crafting a pedagogy for educational change. Peter Lang.

Samaras, A. P., Hicks, M. A., \& Garvey Berger, J. (2004). Self-study through personal history. In J. Loughran et al. (Eds.), The international handbook of self-study of teaching and teacher education practices (part one) (pp. 905-942). Springer.

Sánchez, A. C., \& Obando, G. (2008). Is Colombia ready for bilingualism? Profile: Issues in Teachers' Professional Development, 9, 181-95.

Schön, D. (1986). The reflective practitioner: How professionals think in action. Basic Books.

Seidlhofer, B. (2006). English as a Lingua Franca in the Expanding Circle: What it isn't. In R. Rubdy \& M. Saraceni (Eds.), English in the world: Global rules, global roles (pp. 40-50). Continuum.

Seidlhofer, B. (2011). Understanding English as a Lingua Franca. Oxford University Press.

Shohamy, E. (2006). Language policy: Hidden agendas and new approaches. Routledge.

Shohamy, E. (2009). Language teachers as partners in crafting educational language policies? Íkala, 14(22), 45-67.

Sifakis, N. (2009). Challenges in teaching ELF in the periphery: The Greek context. ELT Journal, 63(3), 230-237. 
Sifakis, N. C. (2014). ELF awareness as an opportunity for change: a transformative perspective for ESOL teacher education. Journal of English as a Lingua Franca, 3(2), 317-335.

Sifakis, N. C., \& Bayyurt. Y. (2017). ELF-aware teacher education and development. In J. Jenkins, W. Baker, \& M. Dewey (Eds.), The Routledge Handbook on English as a Lingua Franca (pp. 456467). Routledge.

Siqueira, S. (2015). Inglês como língua internacional: Por uma pedagogia intercultural crítica. Estudos Linguisticos e Literários, 52, 321-356.

Schneider, E. W. (2018). World Englishes. Oxford research encyclopedia of Linguistics. Oxford University Press.

Spolsky, B. (2017). Language policy in education: History, theory, praxis. In T. McCarty \& S. May (Eds.), Language policy and political issues in education (3rd ed.). Springer International Publishing.

Tollefson, J. W. (Ed.) (2002). Language policies in education: Critical issues. Lawrence Erlbaum.

Ur, P. (1997). Teacher training and teacher development: A useful dichotomy? The Language Techer, 21(10).

Usma, J. (2009). Education and language policy in Colombia: Exploring processes of inclusion, exclusion, and stratification in times of global reform. Profile: Issues in Teachers Professional Development, 11, 123-141.

Valencia, M. (2013). Language policy and the manufacturing of consent for foreign intervention in Colombia. Profile: Issues in Teachers' Professional Development, 15(1), 27-43.

Vanegas Rubio, L. E., \& Zambrano Castillo, L. C. (1996). Plan de capacitación de inglés para profesores de primaria zona urbana del municipio de Neiva, Nivel introductorio I-II. Paideia Surcolombiana, 1(4), 37-44. https://doi.org/10.25054/01240307.931

Vélez-Rendón, G. (2003). English in Colombia: A sociolinguistic profile. World Englishes, 22(2), 185-92. https://doi.org/10.1111/1467-971X.00287

Viáfara J. (2016). "I'm Missing Something": (Non) Nativeness in Prospective Teachers as Spanish and English Speakers. Colombian Applied Linguistics Journal, 18(2), 11-24. http://dx.doi. org/10.14483/calj.v18n2.947

Wallace, S. (Ed.) (2009). A Dictionary of education. Oxford University Press.

Weltens, B., \& Grendel, M. (1993). Attrition of vocabulary knowledge. In R. Schreuder \& B. Weltens (Eds.), The bilingual lexicon. John Benjamins Publishing Company.

Weltens, B., \& Cohen, A. (1989). Language attrition research: An introduction. Studies in Second Language Acquisition, 11(2), 127-133.

Zambrano Leal, A. (2012). Formación docente en Colombia. Arqueología de la política pública y del escenario internacional. Educere, 16(54), 11-19. 